\title{
MICRO-PROCESSES OF TRANSLATION IN THE TRANSFER OF PRACTICES FROM MNE HEADQUARTERS TO FOREIGN SUBSIDIARIES: THE ROLE OF SUBSIDIARY TRANSLATORS
}

\author{
Abstract \\ Recent research has increasingly emphasized the micro-foundations of knowledge transformation in \\ multi-national enterprises (MNEs). Although the literature has provided ample evidence of the \\ enablers of and barriers to the translation of practices, less is known about the activities and efforts of \\ translators that lead to specific types of translation in the context of the transfer of practices initiated \\ at a MNE's headquarters (HQ) to foreign subsidiaries. We apply a Scandinavian institutionalist \\ approach to examine the translation of corporate social responsibility reporting, an HQ-initiated \\ practice that is transferred to five foreign subsidiaries of a UK-based MNE. Our paper builds from a \\ preliminary framework based on extant research to develop an extended framework of the micro- \\ processes of translation. By theorizing the sequence of the micro-processes undertaken by translators, \\ identifying the conditions under which they occur, and connecting them to the three types of \\ translation, we provide a deep understanding of the micro-foundations of translation when transferring \\ practices from HQ to subsidiaries. Our paper shows that translation is an evolving phenomenon and \\ illuminates the importance of attending to the social, spatial, and temporal situatedness of translators. \\ It also brings insights into the individual experience of institutional distance and its effects on \\ translation.
}

Keywords: micro-foundations; transfer of practices; institutional theory; translation; corporate social responsibility reporting; subsidiary managers; multinational enterprises (MNEs); case-theoric approaches. 


\section{INTRODUCTION}

The transfer of practices between the headquarters (HQ) of a multinational enterprise (MNE) and its subsidiaries has been a central concern in the international business literature (Ferner, Almond, \& Colling, 2005; Jensen \& Szulanski, 2004; Kostova, 1999). Scholars have increasingly suggested that HQ-initiated practices cannot simply be transferred to subsidiaries but need to be adapted and modified (Ansari, Reinecke, \& Spaan, 2014; Jensen \& Szulanski, 2004) to achieve deeper internalization rather than superficial acceptance (Kostova \& Roth, 2002). MNE scholarship has developed an interest in the process of translation (i.e., the transformation mainly of language and symbolic aspects of knowledge) involved in the transfer of practices across different institutional contexts (Becker-Ritterspach, 2006; Becker-Ritterspach, Saka-Helmhout, \& Hotho, 2010; Bresman, 2013; Carlile, 2004; Choi \& Johanson, 2012; Monteiro \& Birkinshaw, 2017; Saka, 2004). As a result, there is a fairly solid understanding of the enablers of and barriers to the translation of transferred practices. However, less is known about the micro-processes that individuals deploy to translate organizational practices that are being transferred. We refer to these individuals as translators. Translators are in decision-making positions and, individually or as part of a team, receive the transferred practice and perform each sequence of translation. While prior work has demonstrated that translators use different types of translation (e.g., Gond \& Boxenbaum, 2013), research has not attended to the activities and efforts of MNE translators that lead to specific types of translation. Instead, research has offered anecdotal explanations of "limited" and "comprehensive" translations (e.g., Becker-Ritterspach et al., 2010; Bresman, 2013; Saka, 2004) and investigated the contexts and outcomes of the processes (e.g., Beamond, Farndale, \& Härtel, 2016; Becker-Ritterspach et al., 2010).

There has been increasing interest in the micro-foundations (i.e., individuals, processes, structures) (Felin, Foss, Heimeriks, \& Madsen, 2012) of knowledge transformation in the adjacent field of MNE knowledge management. This scholarship has started to unpack existing models of knowledge flows, which have often treated subsidiaries as monolithic entities (Tallman \& Chacar, 2011; Tippmann, Scott, \& Mangematin, 2014b). Research has investigated the activities of subsidiary managers in seeking solutions in problem-solving processes (Tippmann, Scott, \& Mangematin, 2012) and the dynamics of learning by the communities of practice (i.e., localized groups of individuals) in the 
absorption and dissemination of knowledge (Tallman \& Chacar, 2011). Scholars have also identified boundary spanners (i.e., employees who engage in and facilitate significant interactions between groups) who apply their diverse knowledge in innovative and creative ways (Tippmann, Scott, \& Parker, 2017) and build organizational structures for integrating new knowledge (Roberts \& Beamish, 2017). Despite progress in capturing the work of individuals and collectivities in the transformation of knowledge and their manifestations of agency in MNE knowledge flows, studies of micro-processes of knowledge transformation are largely focused on "emergent" flows (i.e., explorative knowledge exchanges not directly initiated by HQ) (Tippmann et al., 2014b). Scant attention is paid to the microfoundations of translation of "deliberate" flows, as in the transfer of a practice from HQ to subsidiaries.

In summary, research has identified the barriers to and enablers of translation but has not specified the activities and efforts of translators that lead to the specific types of translation in the transfer of practices from HQ to subsidiaries. Nor has research connected these activities and efforts to the identified barriers and enablers. To address this gap, our paper poses the following research question: What are the micro-processes (i.e., the activities undertaken by translators) that lead to specific types of translation in the transfer of a practice from HQ to its subsidiaries? We adopt a theory of translation rooted in Scandinavian institutionalism, which focuses not only on the symbolic transformation (i.e., rhetorical and discursive changes) but also on the material transformation (i.e., structural changes) of practices and emphasizes how institutional context shapes the actions of translators. Drawing on Czarniawska and Sevón (1996) and Sahlin-Andersson (1996), we define translation in the context of the HQ transfer of practices to subsidiaries as the symbolic and material modification that a transferred practice undergoes when it is implemented by translators in the subsidiary.

Unearthing micro-processes in the translation of transferred practices is critical for two reasons. First, HQ may wish to preserve specific aspects of a transferred practice while tolerating some degree of transformation. Knowing how and when translators use a translation type will help HQ limit certain deviations from its prototype. Consider, for example, IKEA's effort to transfer diversity management practices from Sweden to its new affiliate in India (Business Today, 2017) as part of its global lesbian, 
gay, bisexual, transgender/transsexual plus (LGBT+) ${ }^{1}$ inclusion plan (IKEA, 2018). Given the different attitudes toward sexuality, HQ may allow translators discretion to transform networking and mentoring schemes but may want to preserve the overarching global commitment to the UN Standards of Conduct for Business on Tackling Discrimination against LGBT+ People (UN Human Rights Office, 2017). Second, a deeper understanding of the implications of, and approaches to, the translation process will shed light on whether different translation types are more successful at achieving certain organizational outcomes (e.g., employee motivation in IKEA). However, to establish a causal link, it is necessary to identify the micro-processes that lead to each type of translation.

Our paper examines the translation of corporate social responsibility reporting (CSRR), the global practice (Marano, Tashman, \& Kostova, 2017; Tashman, Marano, \& Kostova, 2018) of a company’s public disclosure of its CSR activities and its environmental and social impacts through the publication of stand-alone reports or inclusion in annual reports (Maignan \& Ralston, 2002). We conducted a qualitative study of five subsidiaries of a UK-based MNE in which HQ initiated the transfer of CSRR and translators at the subsidiaries were responsible for interpreting and articulating the transferred practice to the subsidiary. Given the limited understanding of the micro-foundations of translation in the transfer of practices between HQ and subsidiaries, theory-generating research is needed. Our theory development approach is not purely inductive but rather integrates existing theory and initial conceptual categories in the analysis (Miles \& Huberman, 1994; Robinson, 1951). We build a preliminary framework that incorporates three types of translation proposed by Gond and Boxenbaum (2013) and prior research on enablers of and barriers to translation (e.g., BeckerRitterspach, 2006; Bresman, 2013; Carlile, 2004; Choi \& Johanson, 2012; Monteiro \& Birkinshaw, 2017; Saka, 2004). We expand on this framework by identifying a sequence of micro-processes in which the three types of translation emerge. By mapping these micro-processes, identifying the conditions under which they occur, and connecting them to the three types of translation, we provide a deep understanding of the micro-foundations of translation when transferring practices from HQ to subsidiaries. Our framework illuminates the importance of understanding the social, spatial, and temporal situatedness of translators in the use of specific translation types and demonstrates the 
dynamic, open-ended nature of translation. Finally, we show how institutional distance (i.e., the extent of [dis]similarity between parent- and host-country institutions), a frequently cited barrier to successful transfer, influences the translation of practices.

\section{PRELIMINARY FRAMEWORK OF TRANSLATION OF A TRANSFERRED PRACTICE FROM HQ TO SUBSIDIARIES}

In this section, we review the literature from which we build our preliminary framework. First, we introduce the Scandinavian institutionalist theory of translation and Gond and Boxenbaum's (2013) proposition that translators use three translation types. Second, we focus on the MNE literature and identify the conditions that enable and constrain translation at the institutional, organizational and individual levels, and propose a theoretical link to explain how these conditions shape the microprocesses of translation.

\section{The Scandinavian Institutionalist Approach to Translation}

Translation has been studied from various perspectives reflecting different theoretical orientations (O'Mahoney, 2016). The Scandinavian institutionalist approach is useful in conceptualizing knowledge transformation processes in MNEs because it does not view them as "flows" but rather as sequences of translation without which the transfer of knowledge through time and space is not possible (Czarniawska \& Sevón, 1996). Here, translation refers to how ideas change as they travel from one context to another. However, ideas do not travel by themselves. It is important to know who carries (Sahlin \& Wedlin, 2008) or edits (Sahlin-Andersson, 1996) them. Scandinavian translation scholars argue that the transformation of practices is "in the hands of people" (Latour, 1986: 267). Institutional actors (e.g., members of an organization) are not passive adopters but rather active translators who can, intentionally or not, modify practices (and their organizations). Translation is thus considered inseparable from the translators who are embedded in specific institutional contexts. This paradigm is appropriate for our research because it offers a broad view of translation that surpasses the linguistic and symbolic interpretation dominant in the MNE literature by incorporating: the material transformation of practices (Czarniawska \& Sevón, 1996; Sahlin-Andersson, 1996); the context that influences local interpretations; and the translator's interests and motives related to how institutions are understood and acted upon. 
Types of translation. Prior work drawing from the Scandinavian institutionalist approach to translation has demonstrated that the type of symbolic and material modification undertaken by translators to overcome misfit in their local context can unfold in different ways. In their field-level study of the diffusion of responsible investment (RI) practices from the United States to France and Québec, Gond and Boxenbaum (2013) offer a comprehensive account of three types of translation that sustain the "glocalization" of RI: filtering, repurposing, and coupling. Filtering occurs when actors eliminate or downplay features of the imported practice that may be perceived as illegitimate or unattractive and may block its adoption in the new context. For example, the French actors downplayed the "moral" and "religious" connotations of RI, presenting it as a neutral and objective strategy based on long-term profitability. Repurposing refers to a change of meaning or application to enhance the perceived usefulness or acceptability of a practice in the new context. Thus, the Québec actors redefined RI as a form of "social economy" to restore social justice. Finally, coupling occurs when actors add new material (practice related, symbolic, or discursive) to the imported practice to facilitate its local acceptance. Hence, RI was associated with two large workers' unions' pension funds in Québec, adding to the symbolic value of RI as a "public good."

\section{Enablers of and barriers to MNE translation}

HQ-initiated practices reflect the institutional environment of the country in which they originate (Harzing \& Sorge, 2003). When practices are transferred across borders they may not "fit" with the institutional environment of the recipient country (Fortwengel, 2017; Kostova, 1999). Institutional distance, or the extent of (dis)similarity between the parent and host-country institutions (Kostova \& Roth, 2002), is a known barrier in the dissemination of knowledge (Jensen \& Szulanski, 2004).

Translation scholars have suggested that the degree of translation required for a practice to be adopted in a new setting depends on the institutional distance from the "home" context (BeckerRitterspach et al., 2010; Saka, 2004). The greater the institutional distance between the HQ and its subsidiaries, the more incompatibilities emerge (Becker-Ritterspach, 2006), which has implications for the extent of common ground (i.e., the sum of mutual, common, or joint knowledge, beliefs, and suppositions between the sender and receiver of a practice) (Clark, 1996). The greater the common ground, the easier the translation process should be because both parties share assumptions and 
understandings of the practice (Monteiro \& Birkinshaw, 2017), and thus there is no need to explain the transferred practice to subsidiary employees. However, when common ground is limited, there are few connections, common assumptions, and mutual understandings, and therefore more translation effort is required to address interpretive differences (Carlile, 2004). Excessive incompatibilities may impede even the commencement of translation, particularly if a "not-invented-here" syndrome prevails (Szulanski, 1996). Nevertheless, some degree of distance may be desirable insofar as it can trigger creative translations that blend novelty and familiarity (Becker-Ritterspach, 2006; Monteiro \& Birkinshaw, 2017). It follows that micro-processes of translation may be affected by traditions and institutions which underpin how translators in a given setting engage with new practices.

At the organizational level, MNE governance and human resource management can be used as mechanisms to stimulate the mobilization of knowledge (i.e., searching, identifying, acquiring, utilizing, exchanging). Many such mechanisms have been investigated (Gooderham, Minbaeva, \& Pedersen, 2011; Minbaeva, Mäkelä, \& Rabbiosi, 2012; Minbaeva \& Santangelo, 2017); nevertheless, elements such as organizational design and decision-making structure may hinder or enable microprocesses of translation. Flexible and flat organizational designs, empowerment, and inclusive decision making may encourage subsidiary actors to conduct intensive knowledge searches, to break out of their silos, and to mobilize diverse knowledge components into modified or new routines (Tippmann, Scott, \& Mangematin, 2014a). More hierarchical and rigid organizational contexts are less conducive to sharing knowledge (Minbaeva \& Santangelo, 2017). Although these insights were derived from research on emergent flows rather than our focus of HQ-initiated transfers, the organizational structure of decision-making remains important for the micro-processes of translation of HQ-initiated practices because the goal of the transfer is to replicate a practice to achieve uniformity across the MNE. The HQ may oversee the process and limit the translators' scope for change, or it might provide translators with the discretion necessary to modify the transferred practice (or even the organization more widely) to help legitimize the translation (Becker-Ritterspach et al., 2010; Saka, 2004).

At the individual level, human capital (e.g., skills, knowledge, experience, capabilities) (Felin et al., 2012) is also pertinent to understanding the micro-processes of translation. Translators' "related 
experience" enables them to make sense of a transferred practice (Bresman, 2013; Carlile, 2004) and to reconcile potential discrepancies between new and existing practices, and to develop common ground (Monteiro \& Birkinshaw, 2017). Thus, related experience will influence the micro-processes of translation, particularly during early stages when translators are exposed to potentially novel practices (Bresman, 2013).

Actors' boundary-spanning skills may also play a crucial role where there is poor understanding of the opportunities available to transform the practice. Boundary-spanning skills are critical not only to knowledge transfer but also to the more demanding tasks of knowledge transformation (Carlile, 2004; Monteiro \& Birkinshaw, 2017; Saka, 2004; Tippmann et al., 2017). Boundary spanners are individuals who are perceived by members of their in-group and/or relevant out-groups to engage in and facilitate significant interactions between two groups (Barner-Rasmussen, Ehrnrooth, Koveshnikov, \& Mäkelä, 2014). Because they gather and exchange knowledge, and facilitate connections inside and outside the MNE, they are likely to be exposed to a variety of important social interactions through which they develop their understanding and interpretation of new knowledge (Choi \& Johanson, 2012; Monteiro \& Birkinshaw, 2017; Tippmann et al., 2017). In the context of transferring practices from HQ to subsidiaries, we expect boundary spanners to possess mediating skills necessary to engage in the micro-processes of negotiating HQ expectations and subsidiary interests (Carlile, 2004).

Together, these arguments suggest that institutional distance, the organizational structure of decision making, and individuals' related experience and boundary-spanning skills serve as barriers to or enablers of translation and are therefore crucial in understanding translators' activities. Whilst other organizational conditions also influence the transfer of practices (e.g., absorptive capacity [Cohen \& Levinthal, 1990)], identity and trust [Kostova \& Roth, 2002], the nature of tacit versus codified knowledge [Szulanski, 1996]), we focus on those conditions that the MNE literature has explicitly linked with processes of translation and knowledge transformation.

Figure 1 summarizes our preliminary theoretical framework. It outlines the relationships between the conditions we have described at the institutional, organizational, and individual levels and the broad process of translation. However, this framework does not specify the activities and efforts of 
translators or their connection to the three types of translation. To fill this gap, we examine the activities and efforts of translators who were enabled or constrained by institutional, organizational and individual conditions, and who filtered, coupled or repurposed the transferred practice of CSRR.

Figure 1

\section{RESEARCH DESIGN AND METHODS}

Our research design deployed qualitative methods suited to the generation and extended theorization of the micro-processes that lead to specific translation types in the transfer of a practice from an MNE HQ to its subsidiaries. We adopted a semi-structured approach to the analysis. We initially employed analytic induction (Robinson, 1951), which explicitly accommodates existing theory to guide analysis. This approach has been used in fields at an intermediate state of prior theory and research (Edmondson \& Mcmanus, 2007) and is consistent with other common qualitative frameworks (e.g., Miles \& Huberman, 1994) that integrate initial conceptual categories to structure the analysis (e.g., Bansal \& Roth, 2000; Hoffman \& Ocasio, 2001). As the analysis progressed and the focus narrowed to the investigation of micro-processes, our approach became more inductive and aligned both with process research (Langley, Smallman, Tsoukas, \& Van de Ven, 2013) and research aimed at understanding micro-processes within MNEs (e.g., Balogun, Jarzabkowski, \& Vaara, 2011; Tippmann et al., 2012). We adopted an embedded single-case-study design (Yin, 2014), which is appropriate for studying the same phenomenon across different subunits and is aligned with the aim of developing analytically generalizable knowledge.

\section{Case Selection}

We followed the process of theoretical sampling (Patton, 2002) in selecting the case and the embedded units. We examined the translation of a globally legitimate practice in international business (Marano et al., 2017; Tashman et al., 2018): CSRR. CSRR is well-suited to detailed investigation of how translation types unfold in the transfer of practices between HQ and subsidiaries for two reasons. First, CSRR has been adopted by the world's largest MNEs (KPMG, 2017) in order to explain their CSR actions, strategy and objectives. Accordingly, MNE HQs have adopted and transferred processes across their foreign subsidiaries to centrally manage the assessment, measurement, and communication of their progress (Gilbert, Rasche, \& Waddock, 2011). Second, despite the growing international diffusion of CSRR, the literature suggests that country of operation 
and, more specifically, its governance system affect the nature of CSRR (Kang \& Moon, 2012; Kolk \& Pinkse, 2010; Young \& Marais, 2012). We selected five subsidiaries on the basis of their degree of institutional distance from the HQ regarding CSRR. We anticipate that established institutionalized practices in the subsidiaries' host countries would influence the meaning ascribed to CSRR during translation and the extent of common ground, thus enabling us to determine the significance of institutional distance in the use of different translation types. Our chosen MNE provides information, analytical tools, and marketing services to organizations. It also helps individuals manage their credit relationships and minimize the risk of identity theft. Formed in 1996 when UK and US businesses were brought under the same ownership, the MNE demerged from the parent company in 2006 and became an independent company listed on the London Stock Exchange; since when, it has been a FTSE 100 company. Our selected subsidiaries were acquired by the MNE to fill gaps in its portfolio.

The MNE granted us research access in November 2013. Consistent with the recommendation for analytical induction to include subcases that demonstrate diversity in the focal phenomenon (Johnson, 2004), we selected French, Danish, Dutch, Brazilian, and American subsidiaries, which displayed contrasting patterns of translation according to our initial conversations with certain "gatekeepers."2 The subsidiaries also differed in size, age and potentially their degree of autonomy, all of which may influence intra-MNE knowledge flows. ${ }^{3}$ While some effects on the micro-processes of translation might reside in these organizational variables, the variability in these structural contingencies introduced variation in individual-level conditions. It also minimized the chances that our findings would result from a single organizational type, thus increasing their generalizability (e.g., Tippmann et al., 2017). Table 1 summarizes the MNE's and subsidiaries' characteristics.

\section{Table 1}

\section{Data Sources}

Our primary mode of data collection was interviews. They began in 2013 and continued for two years, enabling real-time data collection and translation tracking as it unfolded across the subsidiaries. We used retrospective accounts to obtain insights between 2008 (when transfer was initiated) and 2013. We derived an interview guide from a review of the literature related to our research question. The questions related to employees' experiences with the CSRR translation. The first author conducted 47 
semi-structured interviews at the HQ and the selected foreign subsidiaries (Table 1). We "purposefully" sampled the interviewees (Patton, 2002) on the basis of their involvement in the transfer of CSRR and to reflect a variety of hierarchical positions, functions, levels of expertise, and employment tenure. Most interviews lasted about one hour.

We also collected a wide range of documents, such as the MNE's global CSR reports and annual reports and the Brazilian subsidiary's own CSR reports (the other subsidiaries had none), subsidiaries' website information and internal documents (e.g., guidelines, e-mail conversations between translators and the HQ, video-conference transcripts), business press articles, and national government reports. ${ }^{4}$ We used these sources to identify topics relevant to our research question and key issues to explore with interviewees (Table 2). The documentary data also enabled us to triangulate information gathered from the interviews and to examine the subsidiaries' institutional contexts. We entered the primary data (from interviews) and the secondary data (supplementary documentation) into NVivo software.

\section{Table 2}

\section{Data Analysis}

Stage 1: Organizing data and developing a chronology of events. We relied on techniques of narrative analysis and temporal bracketing to understand our longitudinal qualitative data and to prepare a chronology for subsequent analysis (Langley, 1999). These techniques enabled us to condense data from multiple sources (Miles \& Huberman, 1994) while avoiding loss of relevant information. For each subsidiary, we compiled a chronological list of events related to the translation of CSRR, distinguishing key periods according to a temporal bracketing process, and wrote a raw detailed narrative describing the stages whereby the CSRR was translated.

Stage 2: Identification of translators. We examined the data to identify which actors performed the translation. We did not assume that translators were designated by HQ or that only one individual performed the role. Indeed, in some subsidiaries, translators had assumed the role voluntarily, in the absence of HQ's nomination. We also learned that HQ did not rely on expatriates or international assignees to transfer and translate the practice. Early analysis indicated that the role was performed primarily by individual middle managers who self-identified as having that role, without using the 
word "translation" or "translator" per se. We asked these individuals to provide full descriptions of their roles, their interpretations of CSRR, and how they transformed CSRR for the subsidiary.

Stage 3: Deductive analysis of the three types of translation. We confirmed our supposition that the three translation types (i.e., filtering, coupling, and repurposing) occurred in our subcases. To identify the types of translation used, we distinguished differences between the "prototype" (Ansari, Fiss, \& Zajac, 2010) — the version of the practice originally devised by HQ — and the "actual" transformed versions of the practice observed among the five subsidiaries (e.g., Vigneau, Humphreys, \& Moon, 2015). Interviews at the UK HQ and secondary data helped characterize the CSRR. Our coding framework builds on existing categories in the CSRR literature. Accordingly, we identified: motivations (i.e., reasons for reporting) (Kolk, 2010; Maignan \& Ralston, 2002), distinguishing instrumental, relational, and moral motivations (Aguilera, Rupp, Williams, \& Ganapathi, 2007); reporting standards and guidelines' to which firms adhere (Fortanier, Kolk, \& Pinkse, 2011; Kolk, 2004); reporting scope (i.e., breadth of the report) (Kolk, 2004); systems for organizing reporting (i.e., management systems, calculation of performance indicators and methodologies) (Kolk, 2004); and stakeholder dialogue and feedback (i.e., communication with, and involvement of, internal and external stakeholders) (Kolk, 2004; Young \& Marais, 2012).

The HQ expected each subsidiary to replicate all the items within each category and emphasised instrumental motivations (i.e., attract capital and enhance MNE reputation and competitiveness). The HQ restricted the development of local CSR reports and the publication of website information about subsidiaries' CSR and discouraged subsidiaries from signing the United Nations Global Compact (UNGC) and from independently adhering to the Global Reporting Initiative. The HQ also centrally managed the stakeholder dialogues. Table 3 presents the CSRR prototype.

\section{Table 3}

After examining the actual transformed version of the practice across the subsidiaries and identifying symbolic (e.g. changes in meanings, values, drivers) and material (e.g. changes in routines, physical artifacts) modifications, we generated a meta-matrix by "stacking" the five subcases under the categories of the coding framework (Miles \& Huberman, 1994). This facilitated cross-case comparison and enabled us to identify gaps between the HQ's CSRR prototype and the transformed 
versions. From this we compiled a list of deviations (see second column of Table S1 in the Supplementary Appendices) and assessed how these clustered into specific types using constant comparison between theory and data. We found that most items clustered into Gond and Boxenbaum's (2013) three proposed translation types. However, we also found that the translator within each subsidiary adopted one dominant type of translation throughout the study period (filtering in the French subsidiary; coupling in the Dutch subsidiary; and repurposing in the Brazilian, Danish, and American subsidiaries). Although translators used other types (e.g., the Danish and American translators also engaged in coupling), this was not sufficient to denote the use of multiple types of translation: dominant types prevailed.

Stage $4^{5}$ : Identification of micro-processes. Our approach became more inductive as we focused on identifying the micro-processes that led to the three types of translation. Translation types refer to the symbolic and material transformations of the transferred practice and were empirically observed through changes that the prototype underwent (e.g., "minimizing the prominence of the competitiveness aspect of CSRR"). Micro-processes refer to the sequenced activities, efforts and experiences of translators that unfolded before and after the transformation of the transferred practice, and thus are not directly performed on the practice (e.g., "monitoring competitors' behavior"). Relying on the chronological bracketing from Stage 1, we identified texts in our database from the accounts of our respondents and from the translators themselves that described or provided evidence of these micro-processes. Following the Gioia methodology (Gioia, Corley, \& Hamilton, 2013), we developed NVivo codes that corresponded to the actors' activities (e.g., "drawing comparisons between transferred and existing practices," "using moral accounts") and reflected the language the respondents used (first-order concepts). Subsequently, we integrated the first-order codes into higherorder theoretical categories (second-order themes) from which we inferred seven micro-processes related to the translation of transferred practices: assessing the (in)compatibility of the practice, experiencing ambiguity, searching for knowledge, identifying opportunities, articulating a narrative, re-architecting, and resolving tensions. Table 4 presents the data structure resulting from our overall analysis.

\section{Table 4}


Stage 5: Identifying the contextual conditions of the micro-processes. Consistent with our analytic induction approach, our analysis moved between preconceived categories derived from our preliminary framework in which the data were categorized into the pre-set factors (Miles \& Huberman, 1994) (i.e., institutional distance, structure of decision making, the translator's related experience, the translator's boundary-spanning skills) and an inductive process whereby segments of data were identified and grouped so that novel categories could emerge. Because some codes were 'partially emergent', we used categories that were more descriptive than analytical (e.g., "absence or presence of CSRR regulation," "sense of being controlled by HQ," "leveraged institutional differences," "financial support from HQ"), and developed theoretically "tighter" categories as the analysis proceeded. Inconsistencies between existing theoretical constructs and our empirical observations led us to further analysis and theorizing of the micro-processes. For example, we identified that the effects of institutional distance on the translators' interpretation of the practice were better captured in a micro-process in which translators experienced more or less ambiguity in relation to those differences. While we had expected "related experience" to be a key enabler of the process, this did not fully fit with our empirical observations. Having direct knowledge of the practice was important but so was the degree to which the practice was reinforced by institutions in the subsidiaries' field; the translators' awareness of it; and whether or not they identified with the practice. Indeed, some translators were unaware of national regulations that addressed CSRR, which is consistent with the idea in the literature on the micro-foundations of institutional theory that whether individuals support and incorporate a practice or resist it depends on their degree of adherence to the logics of the practice (Besharov \& Smith, 2014; Pache \& Santos, 2013).

Similarly, we identified that boundary-spanning positions and multiple groups (rather than the skills of boundary spanners) maximized translators' opportunities to find relevant knowledge within the micro-process of searching for knowledge. Some translators did not hold a boundary-spanning position and thus were deprived of these opportunities. We labelled this condition positioning of the translator, drawing on Becker-Ritterspach (2006) and Regnér and Edman (2014). An important discovery at this stage of the analysis was the realization of the salience of temporal orientation - that is, whether translators were more oriented to the present or the future in the micro-processes of 
translation. This led us to draw on theories of agency and temporal embeddedness (Battilana \& D' Aunno, 2009; Emirbayer \& Mische, 1998) to analyze the data. These perspectives stress that the ways in which people understand their own relations to the past, future, and present make a difference to their actions (i.e. their sense of agency). During our analysis, we considered whether translators' temporal orientation could enhance or deter certain micro-processes. We found that translators possessed some leeway to transform the practice in the initial micro-processes of translation. Subsidiary translators only experienced constraints on their decision making in the last micro-process: resolving tensions. We also noted that the independence to use subsidiary resources related to the transferred practice facilitated the initiation of organizational changes in the re-architecting (i.e., upgrading the organizational structure).

Thus, our framework incorporates four contextual conditions: translators' adherence to the practice (i.e., CSRR), translators' positioning (i.e., boundary-spanning or not), translators' temporal orientation, and translators' autonomy over practice-related resources.

Stage 6: Developing the temporal dynamic of the micro-processes. We adopted a visual mapping strategy (Langley, 1999) to represent the micro-processes leading to the three types of translation and to enable a search for common sequences of events. We then analyzed how the conditions identified in Stage 5 affected subsequent micro-processes (Langley et al., 2013) and identified key turning points. For example, we observed that the extent to which a translator's ambiguity led to a process of either searching for knowledge (in conditions of more ambiguity) or identifying opportunities (in conditions of less ambiguity). We also found that coupling and repurposing required the identification of related knowledge either as the outcome of searching for knowledge or as the experience of low ambiguity given extensive common ground and a shared understanding about the practice between HQ and the subsidiary. There was an overall progression of the micro-processes through three stages that we labelled making sense, reconciling, and anchoring.

The framework (Figure 2) emerged from four iterations of data analysis ${ }^{6}$ in which we compared the findings against existing theory (Figure 1) and discussed the findings among ourselves and with other researchers. We stopped iterating between theory and data when we reached theoretical 
saturation (Eisenhardt, 1989) i.e. the incremental improvement to our framework became minimal. Thus, Figure 2 is a theoretically refined version of Figure 1 based on our inductive analysis.

Several procedures give us confidence in the trustworthiness of our findings (Cuervo-Cazurra, Andersson, Brannen, Nielsen, \& Reuber, 2016). We ensured data reliability by following the predesigned interview protocol and developing a case database. To develop valid theory, we adopted a synchronic (i.e., interviewing various respondents on the same topic) and a diachronic (i.e., interviewing the same respondent on a particular topic more than once) primary data source triangulation approach (Pauwels \& Matthyssens, 2004). To minimize the risk of ex post rationalization, we separately asked various informants from different hierarchical levels to describe and interpret the same concrete events, which allowed us to validate the plausibility of their accounts. To achieve a balance between etic and emic perspectives, we kept data in the original language but created codes in English as the common language of analysis. To increase intercoder reliability (Miles \& Huberman, 1994) in Stages 3-5, the first author coded and initially analyzed data, while the second author played the role of the second coder. We resolved coding inconsistencies through discussion.

\section{FINDINGS}

We first present our extended framework of the micro-processes of translation of a transferred practice between the HQ and its subsidiaries. We then describe these micro-processes in greater detail, beginning with the initial transfer of CSRR from HQ and moving through the three stages of making sense, reconciling, and anchoring. We present illustrative examples from selected cases. Table S2 (supplementary appendices) provides additional data for each micro-process.

Figure 2

\section{An Extended Framework of the Micro-Processes of Translation of a Transferred Practice from HQ to Subsidiaries}

Our framework shows the actions and activities of subsidiary translators that lead to specific types of translation when transferring a practice from HQ to subsidiaries. There are seven micro-processes (Figure 2) that occur in a specific sequence: (1) assessing the (in)compatibility of the practice, (2) experiencing ambiguity, (3) searching for knowledge, (4) identifying opportunities, (5) articulating a narrative, (6) re-architecting, and (7) resolving tensions. These seven micro-processes are clustered into three distinct stages: (1) making sense, (2) reconciling, and (3) anchoring. The micro-processes 
also embed three types of translation: (1) filtering, (2) coupling, and (3) repurposing (Gond \& Boxenbaum, 2013). Finally, the framework distinguishes four contextual conditions (all relating to the translator) that block or enable these micro-processes: (1) the translator's adherence to the practice (CSRR), (2) positioning (boundary-spanning or otherwise), (3) temporal orientation (present or future), and (4) autonomy over practice-related resources.

In the first micro-process, assessing the (in)compatibility of the practice, subsidiary translators evaluate the fit of the transferred practice with their national context. This is followed by the second micro-process, experiencing ambiguity, in which translators encounter uncertainty due to contradictions between what is being transferred by the HQ and prior practices. The translators' adherence to the transferred practice (the first contextual condition) — whether the translators are acquainted to the practice, possess available knowledge and feel committed to it (Besharov \& Smith, 2014; Pache \& Santos, 2013) — informed whether they deemed the transferred practice compatible with their subsidiary's context and whether they experienced more or less ambiguity.

In highly ambiguous situations, translators face more pressure to overcome discrepancies, which leads them to engage in the third micro-process, searching for knowledge. This micro-process involves purposefully seeking knowledge related to the transferred practice that can help them understand, interpret, and transform the practice. The positioning of the translators (the second contextual condition) within the MNE and in the host country influences this knowledge seeking. If the search is unsuccessful, the translators engage in the filtering translation type, whereby beliefs, values, or material features of the transferred practice are eliminated to prevent negative connotations and rejection by employees in the subsidiary. Conversely, if translators find relevant knowledge and common ground, and therefore experience less ambiguity, they engage in a fourth micro-process, identifying opportunities, in which they determine the scope and rationale for transformation. The influence of the translators' temporal orientation (the third contextual condition) - defined as the translators' cognitive understanding of the relationship between the transferred practice and time - is critical in this micro-process because it influences whether translators couple or repurpose the transferred practice. Translators who are oriented to the present are focused on responding to the demand of introducing the new practice in "real time" without anticipating future outcomes. They rely 
on improvised solutions to the contingencies of the "here and now". Mindful of the connections to existing knowledge, present-oriented translators engage in the coupling type of translation and add new material to the transferred practice or combine it with widely accepted practices and material artifacts in the subsidiary. However, if translators are more future oriented, they engage in the imaginative generation of possible future trajectories of the translated practice. The identification of future opportunities triggers the "projectivity" of translators who become more strategic. In this situation, translators focus on repurposing the practice and change its meaning or assign a new application in a different area to enhance its perceived usefulness and acceptability in the subsidiary.

Given the extensive transformation that repurposing requires, two additional micro-processes unfold in this pattern: articulating a narrative and re-architecting. In the former, translators devise a storyline that legitimizes the transformation. In the latter, translators restructure some aspects of the organization so that it fits better with the new practice. A translator's autonomy over practice-related resources - i.e. the degree of independence over resources to fit the practice to the subsidiary's context - is a key determinant in their ability to re-architect the organization. The last micro-process, resolving tensions, emerges across the three types of translation - i.e. when translators address disagreements arising when other actors realize that their interests conflict with the transformation.

Finally, there is a dynamic component in our framework. Specifically, if there is not a straightforward resolution to these tensions, translators will iterate the translation process, though they do not necessarily need to start from the first micro-process.

\section{8: HQ Initiates the Transfer}

The MNE adopted CSRR and published its first global report in 2007. In 2008, as a response to shareholder pressure and competitor behavior, HQ began transferring CSRR to selected subsidiaries with the intention of standardizing the processes of collecting and aggregating data, and of communicating the MNE's social and environmental impact. Subsequently, HQ transferred the practice to the remaining subsidiaries. The MNE did not follow any international framework for reporting (e.g., the Global Reporting Initiative [GRI]) but developed its own systems to support the complex task of collecting data across different locations. 
In 2008, the MNE adopted a global CSR policy and introduced aspects of ISO 14001 policy and environmental codes of conduct. In 2009, HQ developed a data-gathering and performancemanagement system. This was supported by a global intranet platform and a set of reporting principles and methodologies that defined specific indicators and items to be calculated, thus providing a framework to guide each subsidiary in how to perform environmental and social reporting. Individuals from the MNE's 37 subsidiaries were asked to become voluntary "data providers" and to report monthly. The data were usually approved by the country manager and subsequently reviewed by the regional manager. The HQ's CSR department aggregated and audited the data and assembled a provisional report with the support of an assurance company. Data were audited only at HQ level. In the final stage, regional managers and the global CSR team evaluated the reporting process and the five regional offices ${ }^{7}$ were asked by HQ to explain their performance. As of 2015, CSRR covered six areas (employee diversity, health and safety, employee engagement, community investment, waste, $\mathrm{CO}_{2}$ emissions) and comprised 22 specific indicators.

A single middle manager at each subsidiary performed the translation. These were in human resources (French, Dutch subsidiaries), marketing (Danish), and CSR (American, Brazilian). They were briefed by the Global Head of CSR, receiving a pack including "CSR Reporting References" and the "Manual for Social and Environmental Indicators." Here, translators learned that the CSR report would be addressed primarily to the investment community to attract capital but would also be used as a tool for "risk management" and "talent attraction." We learned from the interviews at HQ and from disseminated documents that CSRR would include an assessment of the MNE's CSR performance and would inform any changes in CSR strategy. As explained earlier, the HQ imposed a centralized policy to support global reporting restricting specific practices at the subsidiary level.

Table 3 summarizes the CSRR prototype that HQ devised.

\section{Stage I: Making Sense}

Assessing the (in)compatibility of the practice. This micro-process that unfolded after the transfer of CSRR was assessing the (in)compatibility of the practice, which was associated with two activities: negatively defining CSRR and drawing comparisons. In negatively defining CSRR, translators drew from their own experiences and defined the practice by describing what it is not, which helped 
highlight potential differences from existing subsidiary practices. One translator stated that "CSRR is not a source of competitiveness in France," while another translator voiced that "a global CSR report in English is not a local report in Brazil.” In making such assessments, the translators associated CSRR with familiar practices. For example, one translator compared CSRR to "a mechanistic task often reduced to fill[ing] in a spreadsheet" and associated the public disclosure of CSR achievements with "American culture." Often, translators combined both actions, as illustrated in an email response to HQ's CSRR briefing:

"CSRR is a practice that is not embedded in Dutch society, not as much as you would like. CSRR is a private initiative. The Netherlands is one of the countries where this is well organised by the government. It is growing in Dutch society but it's not as extensive as it is in the US." (Dutch translator)

We noticed that these definitions and comparisons were driven by the translators' direct knowledge and awareness of, and their commitment to, CSRR, or their "degree of adherence" to the practice (Besharov \& Smith, 2014; Pache \& Santos, 2013). For most translators, the CSRR concept was not entirely novel: some had experienced the practice and its associated institutional demands. The Danish translator was a strong advocate of CSRR as his subsidiary had significant experience with reporting regulations (e.g., he mentioned the Law of Green Accounts, 1995 and the Financial Statements Act, 2008). He also positively identified with the government's ambition to promote transparency and develop the international competitiveness of Danish firms. However, other translators displayed weak adherence to CSRR. The French translator, for example, ignored French CSRR developments (e.g., the Law of New Economic Regulations 2002; the Law Grenelle II, 2000 [IRSE, 2012]) because of their weak legal enforcement. Our analysis suggests that by negatively defining CSRR and drawing comparisons - informed by their degree of adherence to the practice the translators were able to disembed the prototype from its original institutional context (Czarniawska \& Joerges, 1996), reflect on the practice, and assess its compatibility with their respective subsidiaries.

Experiencing ambiguity. Incompatibilities and contradictions identified in the first micro-process trigger ambiguity, which leads translators to experience uncertainty. Two activities were identified in this micro-process: having doubts about the practice and lacking common ground. In the former, 
translators raised concerns about specific aspects of CSRR and reported unease, illustrated by the Brazilian translator:

"With the transferred practice, we have global targets and we need to achieve them.... It's not easy because sometimes we don't participate in the creation of these targets. I don't know how they measure them, so it's a little bit difficult... I am not comfortable because it's important to build these strategies together."

Such comments confirm our assumption that translators in subsidiaries with more incompatible institutional environments experience less common ground. The instances where translators expressed a lack of common ground (e.g., over the meaning of CSRR) were inherently related to differences between their subsidiaries' institutionalized practices and the intended CSRR. Some translators defended their own practices and considered CSRR's instrumental motives to be "at odds" with employee morale and sense of belonging to the company, both of which are relational in nature (Aguilera et al., 2007). Despite the many utterances of "this doesn't make any sense" and "this is not how we do things here," some translators indicated the existence of common ground. Although the Danish subsidiary had not published a CSR report before the transfer of CSRR, it had adopted customary processes to record and monitor the organization's social and environmental performance which, according to the translator, were "inherent in the business" but not organized under the "CSRR label.” Similarly, the American translator identified extant processes to collect data regarding community involvement and employee volunteering (the subsidiary's major CSR activities) before the CSRR transfer.

Our analysis suggests that when translators adhere strongly to CSRR, they experience less ambiguity. In this situation, common ground generates a greater scope for identifying opportunities to transform the practice. Thus, these translators do not need to engage in a micro-process of searching for knowledge. Conversely, when translators encounter more discrepancies and contradictions, they experience greater ambiguity because their exposure to the transferred practice disrupts entrenched routines and local meanings (Sahlin-Andersson, 1996). When there is a lack of common ground, translators struggle to identify clear solutions to render the practice appropriate to their context (Morris \& Lancaster, 2006). Thus, they engage in the micro-process of searching for knowledge. 


\section{Stage II: Reconciling \\ Searching for knowledge. In this micro-process, translators purposefully seek repositories of}

knowledge (e.g., colleagues, national stakeholders, existing practices institutionalized in the subsidiary) to help them attenuate ambiguity and reconcile discrepancies.

Translators accessed specific CSRR-related knowledge through targeted activities such as monitoring competitor behavior, raising queries (e.g., through intranet forums, quarterly meetings, annual corporate conferences), and reaching out to peers and national stakeholders. The Dutch translator searched the subsidiary's competitive environment through a systematic review of the CSRR practices of national competitors: "All the main competitors in the Netherlands are focusing only on the economic side of business; they do not report on their interactions with society."

Evidence suggested that the translator's position could enable (or hinder) searching activities. Some translators occupied boundary-spanning positions insofar as they either internally coordinated the MNE's CSR at the regional or national level or were engaged in CSR with their national subsidiary's network. These boundary-spanning translators quickly became socialized into CSRR despite an initial lack of baseline knowledge. The Dutch translator, who experienced a higher degree of ambiguity, participated in national subsidiary networks, exchanging knowledge about CSRR and fostering links with different stakeholders to enable future collaboration. Through these networks, the translator assimilated tacit knowledge, such as how to interpret the data collected (e.g., the meanings of key performance indicators, impacts on the organization) and how to solve technical issues (e.g., quantification issues, comparability of subsidiaries' data). The translator considered the acquisition of this knowledge a "turning point"; one that shaped his initial understanding of CSRR.

Although some translators engaged in searching, this did not always lead to successfully sourcing relevant knowledge. This was the experience of translators with only limited interaction with other subsidiary actors and outside stakeholders, thus underscoring the notion that translations are socially conditioned by the translators' positioning (Becker-Ritterspach, 2006).

Translators with little exposure to CSRR knowledge and few cognitive tools to adjust the transferred practice perceived the work of translation as too onerous. Fearing the rejection of the practice among subsidiary employees, these translators considered that the least troublesome response 
would be to suppress or camouflage the features of CSRR which they perceived to be dissonant with national practices and values. The French translator offers a striking case of filtering by minimizing the "competitiveness" connotation of CSRR. Instead, the translation enhanced elements such as "employee morale" to help legitimize it. Similarly, the translator downplayed the reputational connotation of CSRR because it clashed with the French view that corporations' discretion about their good deeds was proof of sincerity.

Identifying opportunities. Translation requires blending familiarity and novelty (SahlinAndersson, 1996). Without having the adequate level of shared understanding, translators cannot move to the next stage of resolving how to transform the practice. As our framework shows, once translators have identified relevant knowledge (after a search) or if their contexts are compatible with the translated practice (i.e., they experience less ambiguity and encounter common ground), they engage in a micro-process of identifying opportunities to determine the rationale and scope underlying the transformation.

Our data show that this micro-process is shaped by translators' temporal orientation. Futurefocused translators identified opportunities by envisioning the CSRR trajectory in relation to anticipated national and global events. The Brazilian translator factored in future regulation and increased expectations of transparency in his approach to reconfiguring CSRR:

"I think that the government, at least in the sustainability agenda, will bring in more regulation. We try to work with other companies and learn together how to be more transparent. Giving information like this [CSRR] tends to be seen by society as a black box."

Similarly, the Danish translator sought to modify CSRR so that it would align better with the Danish government's ambition to tackle climate change, promote transparency and respect for human rights. Future-oriented translators also identified opportunities for CSRR to be implemented to improve firm-specific issues. The Danish translator applied similar methodologies to those stipulated by the $\mathrm{HQ}$ to measure waste and $\mathrm{CO}_{2}$ emissions (Table 3) to track the subsidiary's energy efficiency, which provided valuable information to the translator regarding potential cost savings. We cannot confirm whether this led to savings, but the data indicate that the translator examined possible future effects of changing the scope of CSRR. 
These translators did not merely replicate the transferred practice prototype; rather, they wanted to transform CSRR and give it a novel purpose that would resonate with their interest and the subsidiaries' future position (Sahlin-Andersson, 1996). In the Brazilian subsidiary, CSRR was repurposed from a purely "instrumental tool" into a "relational device." The Brazilian translator described CSRR's main purpose as generating public-private partnerships, incentivized by long-term government policy. CSRR stimulated the Danish subsidiary's focus on energy efficiency and was repurposed to generate information useful to the translator's engagement in political activities in national climate change discussions.

In the US case, repurposed CSRR shifted from a tool of risk and reputation management to one of stakeholder engagement involving non-traditional stakeholder groups (i.e., special interest groups [SIGs]) concerned with online privacy. The prototype comprised a stakeholder dialogue system organized by the HQ to achieve consistency in messaging. Stakeholders were screened for their expertise relevant to a pressing issue and were invited to join global forums. However, the American translator turned CSRR into a more "intuitive" and unstructured engagement, including adversarial SIGs that were often left out of global consultation processes. The translator considered "openness" fundamental to turn adversarial relationships with SIGs into constructive ones. In all three cases, the subsidiaries' CSRR purpose was strikingly distant from the original (Table 3).

Another kind of behavior emerged that was related to identifying opportunities. Some translators identified translation opportunities to respond to the current dilemma of introducing the new practice in the subsidiary. The Dutch translator expressed his intention to "get on" with the task of using CSSR data to support discussions in the works council:

"I mean, the law on works councils says what subjects you have to discuss, that are mandatory, but if we have some CSR interesting topics [emerging from the report] to share and discuss with employees they are always welcomed."

In these instances, there were no plans to fit the translated practice into future scenarios, suggesting that when the dominant temporal orientation was the present, translators resorted to improvised solutions to couple CSRR with accepted elements in the subsidiary. In the Dutch case, specific passages of the global CSR report were linked to Ruggie's framework ${ }^{8}$ and the UN principles on human rights (even though these were absent from the global CSR report). These passages were 
compiled in a short document written in Dutch and shared informally with stakeholders during townhall meetings. In the US subsidiary, CSRR was coupled with material artifacts when the information in the CSR report was tied to media releases, online dialogues in Google Hangouts, and blogpost forums. Given the similar institutional distance between the two continental European countries (France and the Netherlands) and the UK HQ regarding CSRR, an unanticipated finding is that the Dutch translator managed to couple CSRR while the French counterpart filtered it.

\section{Stage III: Anchoring}

Articulating a narrative. Translators who repurposed the practice engaged in the micro-process of articulating a narrative or "storyline" to persuade the immediate CSRR users by framing the CSRR as either a problem-solving approach or as a moral issue. In the former, translators rationalize why some changes should take place, while in the latter, translators produced ethical rhetoric in support of the CSRR with reference to broadly accepted ideas in society. The Danish translator articulated a narrative of "cutting costs" in three main areas (electricity, heating, $\mathrm{CO}_{2}$ emissions) supporting the repurposed focus of CSRR on energy efficiency. He emphasized causes and effects along with the moral responsibility for mitigating environmental impacts:

"We need to collect this data because we need to know our costs, we need to know where we can save, how we can save. If we can get a greener profile that is a huge benefit for society, but we need to know what our cost percentages are. If you do this, we will save costs and you will have better stories to sell." (Danish translator via videoconference)

The new practice soon gained the approval of users and resonated throughout the subsidiary. Similarly, the American translator used a problem-solving narrative whereby CSRR could be used to appease criticisms from consumer advocacy groups.

Re-architecting. Repurposing also involved a sixth micro-process, re-architecting, which worked simultaneously with articulating a narrative. By re-architecting, the translator restructured some aspects of the organization to fit the repurposed practice. Three activities characterize this microprocess: changing processes, reconfiguring relationships, and introducing new routines. Regarding the first activity, translators realigned their established organizational activities according to the repurposed practice. The Danish translator revised the calculation of some key performance indicators and units of measurement included in the HQ's "Manual for Social and Environmental Indicators." He also requested the provision of tailored data from utility suppliers to calculate new indicators 
relevant to the repurposed CSRR focus on saving costs. By reconfiguring relationships, the translators assigned new responsibilities by modifying of job descriptions, adjusting chains of command, and fostering links with other departments that would be active in the implementation of the repurposed CSRR. Finally, by introducing new routines, translators developed new practices to fill the gaps generated by the repurposed practice. The American translator led the development of new routines by merging employee volunteering data from an existing management system with the new global data-gathering and performance-management system.

In the re-architecting micro-process, we found that translators tailored national CSRR training for their employees, reflecting not only their commitment to guiding employees in the integration of the repurposed practice into operations, but also their access to resources to support these changes.

"We do employee training, from time to time do lunchtime training for employees, so if you think of a communications channel tool I think we use it somewhere.... It's also challenging because they are focused on their day-to-day job and they are flooded with other information coming in." (American translator)

Our data suggest that translators who had autonomy over practice-related resources, specifically the CSR budget, could implement changes in the subsidiary (e.g., US, Brazil).

Resolving tensions. The final micro-process observed across the three types of translation is resolving tensions, which emerged when there were conflicts of interest either between the translator and HQ or among employees in the respective subsidiary. In this context, negotiating terms and making trade-offs were the two key micro-process activities.

The Brazilian subsidiary illustrated how a translator can resolve tensions. This subsidiary had published a CSR report that adhered to the GRI guidelines for five consecutive years, was a signatory to the UNGC and had long-standing national stakeholder engagement. Following its acquisition by the MNE and the transfer of CSRR in 2008, the translator complied with the new global practice, while repurposing it and maintaining some national practices. However, HQ did not share this vision and required some existing arrangements to be discarded or minimized as they were deemed incompatible with an integrated global strategy. This posed a challenge for the translator, as the subsidiary was facing home-country pressures to disclose its ethical credentials following corruption scandals in the financial services industry. In the translator's bargaining with HQ to keep some subsidiary-level existing practices, he defended retaining the relational and instrumental motives for 
the CSRR that preceded the MNE's acquisition of the subsidiary. The Global Head of CSR describes his negotiation with the Brazilian translator over the withdrawal of the national CSR report:

"I mean, when you acquire a company and it becomes part of a public company it has to operate to different standards.... If I'm very honest, they were leading the way; we had to stop them from doing this. I had to negotiate with them and talk about how they were going to be part of the big picture."

Persistent bargaining led to some trade-offs. Thus, while the subsidiary had to cancel its signature to the UNGC and cease publishing a national CSR report, it was allowed to retain its code of ethics and present selected CSRR information on its website. In the US case, HQ perceived the translator's relations with adversarial SIGs to exacerbate reputational risks. However, the translator persuaded HQ to create a unique consumer advocacy council of industry experts, advocacy group members, and top management, to directly oversee those engagements.

The micro-process of resolving tensions also emerged in the filtering and coupling translation types, due to disagreements among employees implementing the practice. In the French case, some employees claimed that the translator had concealed some original aspects of CSRR that they considered inconsistent with their own values. They called for the reinstatement of the instrumental component in CSRR (i.e., creating strategic value for the MNE). Our data collection ended in 2015 and we were unable to trace what transpired, but we suspect that a new iteration of the translation occurred. However, this iteration may not necessarily begin with assessing the (in)compatibility of the practice but rather with a micro-process in the reconciling stage. The details are beyond the scope of this article, but the case illustrates that translation may not have a definitive end-point; rather, it is better characterized as an iterative and dynamic process.

\section{DISCUSSION}

This study was motivated by the limited understanding of the micro-foundations of translation in the transfer of practices from HQ to subsidiaries. The primary goal was to generate and extend theorization on how micro-processes lead to specific types of translation in the transfer of a practice from HQ to subsidiary by drawing attention to the activities of subsidiary translators in deliberate knowledge flows. Our findings depart from the common view of subsidiary managers as implementers of knowledge in deliberate flows, whose activities are less intensive and less creative 
than those in emergent knowledge flows (e.g. Tippmann et al., 2014b). Our study also contributes to understanding institutional distance and translation.

\section{Micro-foundations of Translation of Transferred Practices from HQ to Subsidiaries}

Our paper contributes (1) by theorizing the sequence of micro-processes undertaken by translators that lead to specific types of translation and (2) by connecting enablers of and barriers to those microprocesses. As knowledge management and MNE scholars attend to the micro-foundations of knowledge transformation, their focus has shifted to understanding the conditions that enable and constrain the translation process in the transfer of practices (e.g. Becker-Ritterspach, 2006; Bresman, 2013; Carlile, 2004; Choi \& Johanson, 2012; Monteiro \& Birkinshaw, 2017; Saka, 2004). However, they have not specified the activities of individuals that lead to specific types of translation in deliberate flows of knowledge, such as the transfer of HQ-initiated practices to subsidiaries.

Our framework enhances the understanding of the micro-foundations that underpin translation in the transfer of a practice from HQ to a subsidiary by identifying the role of translators. In particular, we reveal the chain of actions that translators take throughout the transfer process, thus shedding light on translation as an evolving phenomenon (iterative, dynamic, and ongoing) rather than a "one-off" activity (Lawrence, 2017; Tracey, Dalpiaz, \& Phillips, 2018). We show that the process of translation does not end with the transferred practice being filtered, coupled, or repurposed. Rather, translators engage in further activities to anchor the practice in their subsidiary. We show that repurposing requires translators to both undertake comprehensive changes in the organization and engage in rhetorical efforts to anchor the transformed practice, as per Scandinavian institutionalism would lead us to expect. The emergence of the micro-process of resolving tensions across the three types of translation highlights how interests are reshuffled in the translation process. The framework identifies two major turning points that are crucial in explicating how translation develops. The identification of relevant knowledge that results from the micro-process of searching explains the split between filtering and the more intensive types of translation (coupling and repurposing), whereas the bifurcation between coupling and repurposing lies in the translator's temporal orientation. We can also speculate that when conflict is not resolved, a new iteration of the translation will take place, confirming our dynamic perspective. 
We extend prior research by connecting individual conditions to micro-processes and explicating when and how translators filter, couple, or repurpose the transferred practice. A key insight into these individual conditions is that translators who are future-oriented are more likely to undertake transformative efforts (repurposing), which may lead to the development of distinctive subsidiary practices. Our theoretical framework thus establishes the social, spatial, and temporal situatedness of translators that both enables and constrains their ability to filter, couple, or repurpose a practice.

To underscore the significance of our findings, we now compare the preliminary framework of translation of a transferred practice from HQ to subsidiaries derived from the MNE translation and micro-foundations literature (Figure 1) with our extended framework of the micro-processes of translation derived from our inductive analysis (Figure 2). The preliminary framework presented institutional distance, the structure of decision-making, the translator's related experience, and the translator's boundary-spanning skills as key enablers of, and barriers, to translation. But it does not connect these enablers and barriers to specific activities of translation (Figure 1). However, our extended framework (Figure 2) explores these conditions at the individual level, identifies new ones (e.g., the translator's temporal orientation), and connects them to the micro-processes. While the preliminary framework ignores the dynamics of the micro-processes and their consequences for the choice of a specific type of translation, the extended framework unveils the temporality of the translation process and specifies the activities leading to the three translation types. Therefore, Figure 2 offers a richer understanding of the relationship among micro-processes, individual conditions, and the three translation types than Figure 1.

\section{Institutional Distance and Translation of Transferred Practices from HQ to Subsidiaries}

Prior research has often framed distance negatively (Lundan \& Li, 2019) and as a barrier to translation (Becker-Ritterspach, 2006; Becker-Ritterspach et al., 2010; Saka, 2004) predicting that the greater the institutional distance between the HQ and the subsidiaries, the less common ground there is for translation (Monteiro \& Birkinshaw, 2017). Our findings provide partial support for these arguments by showing that translators who strongly adhere to the transferred practice and identify common ground were located in less distant institutional environments. Nonetheless, our findings bring additional nuance to understanding the individual experience of institutional distance and its effects 
on translation by emphasizing the role of individuals as carriers of institutional effects. In our study, institutional distance was a precursor to translators' experience of ambiguity related to their adherence to the transferred practice, but the extent of the institutional (dis) similarity between home and host countries is not sufficient to explain the type of translation chosen by the translator. In situations of similar institutional distances between the HQ and its subsidiaries (e.g., the two continental European subsidiaries in France and the Netherlands), translators did not respond identically using the same type of translation. Relatedly, while repurposing and coupling were used when there was some degree of institutional similarity, these two types also emerge in conditions of greater institutional distance. Our findings suggest that the incompatibilities arising from institutional distance were overcome through a successful micro-process of searching for relevant knowledge, aided by the translator's positioning which led to the identification of opportunities for coupling or repurposing. In other words, repurposing and coupling emerged in distant environments but prompted stronger engagement from translators in order to address the challenge of a lack of common ground. These insights add to recent research on the dynamic view of institutions and MNEs suggesting that institutions and their differences do not constrain MNEs in a fixed or immutable way across countries; rather, there is scope for actors to offset the impact of institutions (e.g., Edwards, Sánchez-Mangas, Jalette, Lavelle, \& Minbaeva, 2016; Ferner, Edwards, \& Tempel, 2012; Fortwengel \& Jackson, 2016; Geary \& Aguzzoli, 2016; Jackson \& Deeg, 2019). Our research thus supports re-evaluations of the assumption that institutions necessarily limit MNE action (e.g., Regnér \& Edman, 2014; Saka-Helmhout, Deeg, \& Greenwood, 2016).

\section{Managerial Implications}

Our findings suggest a critical role for the HQ to set an appropriate context to support translation by harmonizing translators' knowledge before and during translation. In our study, the translation roles were played by middle managers responsible for the transferred practice located in various departments (e.g., Marketing, CSR and HR). Sometimes, these roles were complemented by boundary-spanning positions that provided access to cognitive resources and privileged knowledge, thereby increasing the translators' awareness of alternatives in transforming a practice. However, some translators did not occupy such positions and thus could not access these resources (e.g., tacit 
knowledge), which limited their initial understanding of the transferred practice and their awareness of alternatives that could transform the practice. Thus, HQ could enhance the relational ties between subsidiary translators and boundary spanners who may not necessarily possess knowledge related to the transferred practice but who may facilitate connections to relevant untapped pockets of knowledge in other parts of the MNE. Bringing together boundary spanners and translators through socialization mechanisms (e.g., annual conferences, temporal assignments) may foster important social capital on which these change agents can draw.

Our framework demonstrates that translation work is stepwise requiring distinctive efforts and resources that depend on, and align with, the respective stage and type of translation desired. Our findings show that while the HQ explicitly discouraged some specific practices and emphasized that other features had to be replicated, the boundaries of translation became blurred as translation evolved. When the transfer was initiated in 2008, the expectations from the HQ were communicated to translators but this message was not reinforced in later stages of the transfer and there was little monitoring and control from the HQ. As a consequence, the degree of freedom to translate only became evident after the HQ noticed excessive variation from the prototype. Negotiations to resolve tensions between subsidiary translators and HQ only took place in the last stage of translation, potentially triggering a new process of translation. New cycles of translation bring financial and cognitive costs (Ansari et al., 2014). More importantly, unsuccessful iterations may undermine HQ's legitimacy among the employees responsible for implementing the translated practice, thus rendering the translator's work meaningless. Therefore, in managing the translation of transferred practices, HQ managers need to specify not only which aspects of the prototype are mandatory and which are optional and subject to modification, but also to regularly convey those expectations. Monitoring, ongoing communications, and potential HQ intervention during key stages of the translation may make translation more efficient.

Last but not least, our work demonstrates the value of translation as a source of strategic learning for the MNE. While HQs may not encourage transformations that undermine the MNE's consistency of transferred practices, giving translators some latitude to modify those practices may be propitious for MNE access to valuable subsidiary innovations. As our study demonstrates, the translation of 
CSRR illuminated new opportunities to deploy it more widely (e.g., in political debates around climate change, engagement with non-traditional stakeholders) and led to the development of innovative practices across some subsidiaries. In this respect, optimizing the right balance between practice standardization and allowing local heterogeneity is essential but so too is the development of capabilities to capture and internalize learning generated by translation to develop strategic competences for the whole MNE.

\section{Limitations and Future Work}

A single case has limitations and thus caution should be exercised when generalizing the findings. Nonetheless, our research has yielded a detailed qualitative, longitudinal study covering eight years of translation. One limitation is that our data covering 2008 to 2012 were derived from retrospective accounts, while data for 2013 to 2015 were collected in real time. Respondents' retrospective accounts may be subject to biases and memory gaps (Eisenhardt \& Graebner, 2007). To minimize ex post rationalization, we asked various informants to describe and interpret the same events, allowing us to validate their plausibility. Secondary data collected for the 2008-2012 period enabled further triangulation of our findings.

As we completed our analysis, we suspected that new iterations of translation had already begun, though our data are too limited to detail this. Future research could conceptually extend our framework by examining multiple iterations of translation and the potential co-existence of multiple translation types used by translators over time. A longitudinal perspective is vital given that the process of translation is an evolving one. Once a practice matures and becomes "taken for granted" (Kostova, 1999), there may be less motivation to translate it. However, as translators become more knowledgeable about the practice and HQ-subsidiary power relationships shift (Ambos, Asakawa, \& Ambos, 2011), preferences for translation may change too.

We designed this study to analyze micro-processes that lead to the three types of translation. However, there may be cases in which the translator opts for minimal transformation, such that the transferred practice mirrors the prototype. These cases could emerge when the translator strongly adheres to the practice, when there are strong institutional pressures supporting CSRR, or when the translator is relatively present-oriented. It may also occur when translators want to increase their 
subsidiaries' legitimacy and demonstrate to the HQ that the practice was implemented as intended. In those cases, implementing HQ-mandated practices blindly without adaptation may lead to subsidiaries having low levels of internalization (i.e. commitment to and belief in the validity of the practice itself) (Kostova \& Roth, 2002). Future research on the deliberate transfer of practices may adopt a narrower subsidiary focus and connect micro-processes of translation to organizational-level outcomes such as reputation and financial performance.

Whereas our findings focus on translation performed by one translator in the respective subsidiaries, this does not imply that the collective level is nonexistent or unimportant (Tallman \& Chacar, 2011; Tippmann et al., 2017). We sampled subsidiaries on the basis of their degrees of institutional distance from the HQ regarding CSRR and their heterogeneity of translation patterns. We then investigated who performed translation and the micro-level activities associated with it. We did not purposefully sample for translators or networks of translators transforming different types of practices. Future research could investigate the translation of multiple practices across different MNEs and link the individual and collective work during translation. Finally, our view of translation draws from a specific stream of institutional theory that moves beyond an interpretative view of translation focused on language and symbolic aspects (Bresman, 2013; Carlile, 2004; Monteiro \& Birkinshaw, 2017) by incorporating the material transformation of practices, the institutional context that influences local interpretations, and the translators' interests. We hope that this will prove an attractive avenue for others and inspire future research in knowledge management that investigates the effectiveness of different types of translation in broader MNE processes of competence renewal.

\section{REFERENCES}

Aguilera, R. V., Rupp, D. E., Williams, C. A., \& Ganapathi, J. 2007. Putting the S Back in Corporate Social Responsibility: A multilevel theory of social change in organizations. Academy of Management Review, 32(3): 836-863.

Ambos, B., Asakawa, K., \& Ambos, T. C. 2011. A dynamic perspective on subsidiary autonomy. Global Strategy Journal, 1(3 - 4): 301-316.

Ansari, S. M., Fiss, P. C., \& Zajac, E. J. 2010. Made to fit: How practices vary as they diffuse. Academy of Management Review, 35(1): 67-92.

Ansari, S. M., Reinecke, J., \& Spaan, A. 2014. How are practices made to vary? Managing practice adaptation in a multinational corporation. Organization Studies, 35: 1313-1341.

Balogun, J., Jarzabkowski, P., \& Vaara, E. 2011. Selling, resistance and reconciliation: A critical discursive approach to subsidiary role evolution in MNEs. Journal of International Business Studies, 42(6): 765-786. 
Bansal, P., \& Roth, K. 2000. Why companies go green: A model of ecological responsiveness. Academy of Management Journal 43(4): 717-737.

Barner-Rasmussen, W., Ehrnrooth, M., Koveshnikov, A., \& Mäkelä, K. 2014. Cultural and language skills as resources for boundary spanning within the MNC. Journal of International Business Studies, 45(7): 886-905.

Battilana, J., \& D' Aunno, T. 2009. Institutional work and the paradox of embbeded agency. In B. Lawrence, R. Suddaby, \& B. Leca (Eds.), Institutional work: Actors and agency in institutional studies of organizations: 31-58. Cambridge, UK: Cambridge University Press.

Beamond, M. T., Farndale, E., \& Härtel, C. E. J. 2016. MNE translation of corporate talent management strategies to subsidiaries in emerging economies. Journal of World Business, 51(4): 499510.

Becker-Ritterspach, F. 2006. The social constitution of knowledge integration in MNEs: A theoretical framework. Journal of International Management, 12(3): 358-377.

Becker-Ritterspach, F., Saka-Helmhout, A., \& Hotho, J. 2010. Learning in multinational enterprises as the socially embedded translation of practices. Critical Perspectives on International Business, 6(1): 8-37.

Besharov, M. L., \& Smith, W. K. 2014. Multiple institutional logics in organizations: Explaining their varied nature and implications. Academy of Management Review, 39(3): 364-381.

Birkinshaw, J., \& Hood, N. 1998. Multinational subsidiary evolution: Capability and charter change in foreign-owned subsidiary companies. Academy of Management Review, 23(4): 773-795.

Bresman, H. 2013. Changing routines: A process model of vicarious group learning in pharmaceutical R\&D. Academy of Management Journal, 56(1): 35-61.

Business Today. 2017. "We don't force diversity". https://www.businesstoday.in/magazine/leadership-spotlight/we-dont-forcediversity/story/251186.html. Accesed 26 October 2018.

Carlile, P. R. 2004. Transferring, translating, and transforming: An integrative framework for managing knowledge across boundaries. Organization Science, 15(5): 555-568.

Choi, S.-G., \& Johanson, J. 2012. Knowledge translation through expatriates in international knowledge transfer. International Business Review, 21(6): 1148-1157.

Clark, H. 1996. Using Language. Cambridge, UK: Cambridge University Press.

Cohen, W. M., \& Levinthal, D. A. 1990. Absorptive capacity: A new perspective on learning and innovation. Administrative Science Quarterly, 35(1): 128-152.

Cuervo-Cazurra, A., Andersson, U., Brannen, M. Y., Nielsen, B. B., \& Reuber, R. A. 2016. From the Editors: Can I trust your findings? Ruling out alternative explanations in international business research. Journal of International Business Studies, 47(8): 881-897.

Czarniawska, B., \& Joerges, B. 1996. Travels of ideas. In B. Czarniawska, \& G. Sevon (Eds.), Translating organizational change: 13-47. Berlin: Walter de Gruyter.

Czarniawska, B., \& Sevón, G. 1996. Translating organizational change. Berlin: Walter de Gruyter.

Edmondson, A. C., \& Mcmanus, S. E. 2007. Methodological fit in management field research. Academy of Management Review, 32(4): 1246-1264.

Edwards, T., Sánchez-Mangas, R., Jalette, P., Lavelle, J., \& Minbaeva, D. 2016. Global standardization or national differentiation of HRM practices in multinational companies? A comparison of multinationals in five countries. Journal of International Business Studies, 47(8): 968996.

Eisenhardt, K. M. 1989. Building theories from case study research. Academy of Management Review, 14(4): 532-550.

Eisenhardt, K. M., \& Graebner, M. E. 2007. Theory building from cases: opportunities and challenges. Academy of Management Journal, 50(1): 25-32.

Emirbayer, M., \& Mische, A. 1998. What is agency? American Journal of Sociology, 103(4): 9621023.

Felin, T., Foss, N. J., Heimeriks, K. H., \& Madsen, T. L. 2012. Microfoundations of routines and capabilities: Individuals, processes, and structure. Journal of Management Studies, 49(8): 1351-1374. 
Ferner, A., Almond, P., \& Colling, T. 2005. Institutional theory and the cross-national transfer of employment policy: The case of 'workforce diversity' in US multinationals. Journal of International Business Studies, 36(3): 304-321.

Ferner, A., Edwards, T., \& Tempel, A. 2012. Power, institutions and the cross-national transfer of employment practices in multinationals. Human Relations, 65(2): 163-187.

Fortanier, F., Kolk, A., \& Pinkse, J. 2011. Harmonization in CSR reporting. Management International Review, 51(5): 665-696.

Fortwengel, J. 2017. Practice transfer in organizations: The role of governance mode for internal and external fit. Organization Science, 28(4): 690-710.

Fortwengel, J., \& Jackson, G. 2016. Legitimizing the apprenticeship practice in a distant environment: Institutional entrepreneurship through inter-organizational networks. Journal of World Business, 51(6): 895-909.

Foss, N. J., \& Pedersen, T. 2002. Transferring knowledge in MNCs: The role of sources of subsidiary knowledge and organizational context. Journal of International Management 8: 49-67.

Geary, J., \& Aguzzoli, R. 2016. Miners, politics and institutional caryatids: Accounting for the transfer of HRM practices in the Brazilian multinational enterprise. Journal of International Business Studies, 47(8): 997-1021.

Gilbert, D. U., Rasche, A., \& Waddock, S. 2011. Accountability in a Global Economy. Business Ethics Quarterly, 21(1): 23-44.

Gioia, D. A., Corley, K. G., \& Hamilton, A. L. 2013. Seeking qualitative rigor in inductive research: Notes on the Gioia methodology. Organizational Research Methods, 16(1): 15-31.

Gond, J.-P., \& Boxenbaum, E. 2013. The glocalization of responsible investment:

Contextualization work in France and Quebec. Journal of Business Ethics, 115(4): 707-721.

Gooderham, P., Minbaeva, D. B., \& Pedersen, T. 2011. Governance mechanisms for the promotion of social capital for knowledge transfer in multinational corporations. Journal of Management Studies, 48(1): 123-150.

Harzing, A.-W., \& Sorge, A. 2003. The Relative Impact of Country of Origin and Universal Contingencies on Internationalization Strategies and Corporate Control in Multinational Enterprises: Worldwide and European Perspectives. Organization Studies, 24(2): 187-214.

Hoffman, A. J., \& Ocasio, W. 2001. Not all events are attended equally: Toward a middle-range theory of industry attention to external events. Organization Science, 12(4): 414-434.

IKEA. 2018. Diversity \& inclusion. https://www.ikea.com/gb/en/this-is-ikea/working-at-the-ikeagroup/diversity-inclusion/. Accesed 15 October 2018.

IRSE. 2012. The Grenelle II Act in France: A milestone towards integrated reporting 2-35. Paris Institut RSE Management.

Jackson, G., \& Deeg, R. 2019. Comparing capitalisms and taking institutional context seriously. Journal of International Business Studies, 50(1): 4-19.

Jensen, R., \& Szulanski, G. 2004. Stickness and the adoption of organizational practices in crossborder knowledge transfer. Journal of International Business Studies, 35: 508-523.

Johnson, P. 2004. Analytic induction. In C. Cassell, \& G. Symon (Eds.), Essential guide to qualitative methods in organizational research: 165-179. London: Sage.

Kang, N., \& Moon, J. 2012. Institutional complementarity between corporate governance and corporate social responsibility: A comparative institutional analysis of three capitalisms. SocioEconomic Review, 10(1): 85-108.

Kolk, A. 2004. A decade of sustainability reporting: Developments and significance. International Journal of Environment and Sustainable Development, 3(1): 51-64.

Kolk, A. 2010. Trajectories of sustainability reporting by MNCs. Journal of World Business, 45(4): 367-374.

Kolk, A., \& Pinkse, J. 2010. The integration of corporate governance in corporate social responsibility disclosures. Corporate Social Responsibility and Environmental Management, 17(1): $15-26$.

Kostova, T. 1999. Transnational transfer of strategic organizational practices: A contextual perspective. Academy of Management Journal, 24(2): 306-324. 
Kostova, T., \& Roth, K. 2002. Adoption of an organizational practice by subsidiaries of multinational corporations: Institutional and relational effects. Academy of Management Journal, 45(1): 215-233.

KPMG. 2017. The road ahead: The KPMG survey of corporate responsibility reporting 2017. Netherlands: KPMG International.

Langley, A. 1999. Strategies for theorizing from process data. Academy of Management Review, 24(4): 691-710.

Langley, A., Smallman, C., Tsoukas, H., \& Van de Ven, A. H. 2013. Process studies of change in organization and management: Unveiling temporality, activity, and flow. Academy of Management Journal, 56(1): 1-13.

Latour, B. 1986. The powers of associations In J. Law (Ed.), Power, action and belief: 261-277. London: Routledge and Kegan Paul.

Lawrence, T. B. 2017. High-stakes institutional translation: Establishing North America's first government-sanctioned supervised injection site. Academy of Management Journal, 60(5): 17711800.

Lundan, S. M., \& Li, J. 2019. Adjusting to and learning from institutional diversity: Toward a capability-building perspective. Journal of International Business Studies, 50(1): 36-47.

Maignan, I., \& Ralston, D. A. 2002. Corporate Social Responsibility in Europe and the U.S: Insights from businesses' self-presentations. Journal of International Business Studies, 33(3): 497514.

Marano, V., Tashman, P., \& Kostova, T. 2017. Escaping the iron cage: Liabilities of origin and CSR reporting of emerging market multinational enterprises. Journal of International Business Studies, 48(3): 386-408.

Miles, M. B., \& Huberman, A. M. 1994. Qualitative data analysis: An expanded sourcebook. Thousand Oaks, CA: Sage.

Minbaeva, D., Mäkelä, K., \& Rabbiosi, L. 2012. Linking HRM and knowledge transfer via individual level mechanisms. Human Resource Management, 51(3): 387-405.

Minbaeva, D., Pedersen, T., Björkman, I., Fey, C. F., \& Park, H. J. 2003. MNC knowledge transfer, subsidiary absorptive capacity, and HRM. Journal of International Business Studies, 34(6): 586-599.

Minbaeva, D., \& Santangelo, G. D. 2017. Boundary spanners and intra-MNC knowledge sharing: The roles of controlled motivation and immediate organizational context. Global Strategy Journal, 8(2): 1-22.

Monteiro, F., \& Birkinshaw, J. 2017. The external knowledge sourcing process in multinational corporations. Strategic Management Journal, 38(2): 342-362.

Morris, T., \& Lancaster, Z. 2006. Translating management ideas. Organization Studies, 27(2): 207-233.

Noorderhaven, N., \& Harzing, A.-W. 2009. Knowledge-sharing and social interaction within MNEs. Journal of International Business Studies, 40(5): 719-741.

O'Mahoney, J. 2016. Archetypes of translation: Recommendations for dialogue. International Journal of Management Reviews, 18(3): 333-350.

Pache, A.-C., \& Santos, F. 2013. Embedded in hybrid contexts: How individuals in organizations respond to competing institutional logics. Research in the Sociology of Organizations, 39: 3-35.

Patton, M. Q. 2002. Qualitative research and evaluation methods (3rd ed.). Thousand Okas, CA: Sage.

Pauwels, P., \& Matthyssens, P. 2004. The architecture of multiple case study research in international business. In C. Welch, \& R. Piekkari (Eds.), Handbook of qualitative research methods for international business: 125-143. Cheltenham, UK: Edward Elgar.

Rabbiosi, L., \& Santangelo, G. D. 2013. Parent company benefits from reverse knowledge transfer: The role of the liability of newness in MNEs. Journal of World Business, 48(1): 160-170.

Regnér, P., \& Edman, J. 2014. MNE institutional advantage: How subunits shape, transpose and evade host country institutions. Journal of International Business Studies, 45(3): 275-302.

Roberts, M. J. D., \& Beamish, P. W. 2017. The scaffolding activities of international returnee executives: A Learning based perspective of global boundary spanning. Journal of Management Studies, 54(4): 511-539. 
Robinson, W. S. 1951. The logical structure of analytic induction. American Sociological Review, 16(6): 812-818.

Sahlin-Andersson, K. 1996. Imitating by editing success: The construction of organizational fields. In B. Czarniawska, \& G. Sevon (Eds.), Translating organizational change: 69-93. New York: Walter De Gruyter.

Sahlin, K., \& Wedlin, L. 2008. Circulating ideas: Imitation, translation and editing. In R. Greenwood, C. Oliver, R. Suddaby, \& K. Sahlin-Andersson (Eds.), The Sage handbook of organizational institutionalism: 218-242. London: Sage.

Saka-Helmhout, A., Deeg, R., \& Greenwood, R. 2016. The MNE as a Challenge to Institutional Theory: Key Concepts, Recent Developments and Empirical Evidence. Journal of Management Studies, 53(1): 1-11.

Saka, A. 2004. The cross-national diffusion of work systems: Translation of Japanese operations in the UK. Organization Studies, 25(2): 209-228.

Szulanski, G. 1996. Exploring internal stickiness: Impediments to the transfer of best practice within the firm. Strategic Management Journal, 17(S2): 27-43.

Tallman, S., \& Chacar, A. S. 2011. Communities, alliances, networks and knowledge in multinational firms: A micro-analytic framework. Journal of International Management, 17(3): 201210.

Tashman, P., Marano, V., \& Kostova, T. 2018. Walking the walk or talking the talk? Corporate social responsibility decoupling in emerging market multinationals. Journal of International Business Studies.

Tippmann, E., Scott, P. S., \& Mangematin, V. 2012. Problem solving in MNCs: How local and global solutions are (and are not) created. Journal of International Business Studies, 43(8): 746-771.

Tippmann, E., Scott, P. S., \& Mangematin, V. 2014a. Stimulating knowledge search routines and architecture competences: The role of organizational context and middle management. Long Range Planning, 47(4): 206-223.

Tippmann, E., Scott, P. S., \& Mangematin, V. 2014b. Subsidiary managers' knowledge mobilizations: Unpacking emergent knowledge flows. Journal of World Business, 49(3): 431-443.

Tippmann, E., Scott, P. S., \& Parker, A. 2017. Boundary capabilities in MNCs: Knowledge transformation for creative solution development. Journal of Management Studies, 54(4): 455-482.

Tracey, P., Dalpiaz, E., \& Phillips, N. 2018. Fish out of water: Translation, legitimation, and new venture creation. Academy of Management Journal, 61(5): 1627-1666.

UN Human Rights Office. 2017. Tackling discrimination against lesbian, gay, bi, trans, \& intersex people, standards of conduct for business. https://www.unfe.org/wp-content/uploads/2017/09/UNStandards-of-Conduct.pdf. Accesed 1 October 2018.

Vigneau, L., Humphreys, M., \& Moon, J. 2015. How do firms comply with international sustainability standards? Processes and consequences of adopting the global reporting initiative. Journal of Business Ethics, 131(2): 469-486.

Yin, R. K. 2014. Case study research: Design and methods. Thousand Oaks, CA: Sage.

Young, S., \& Marais, M. 2012. A multi level perspective of CSR reporting: The implications of national institutions and industry risk characteristics. Corporate Governance: An International Review, 20(5): 432-450. 


\section{FIGURES AND TABLES}

Figure 1 Preliminary framework of translation of a transferred practice from HQ to subsidiaries

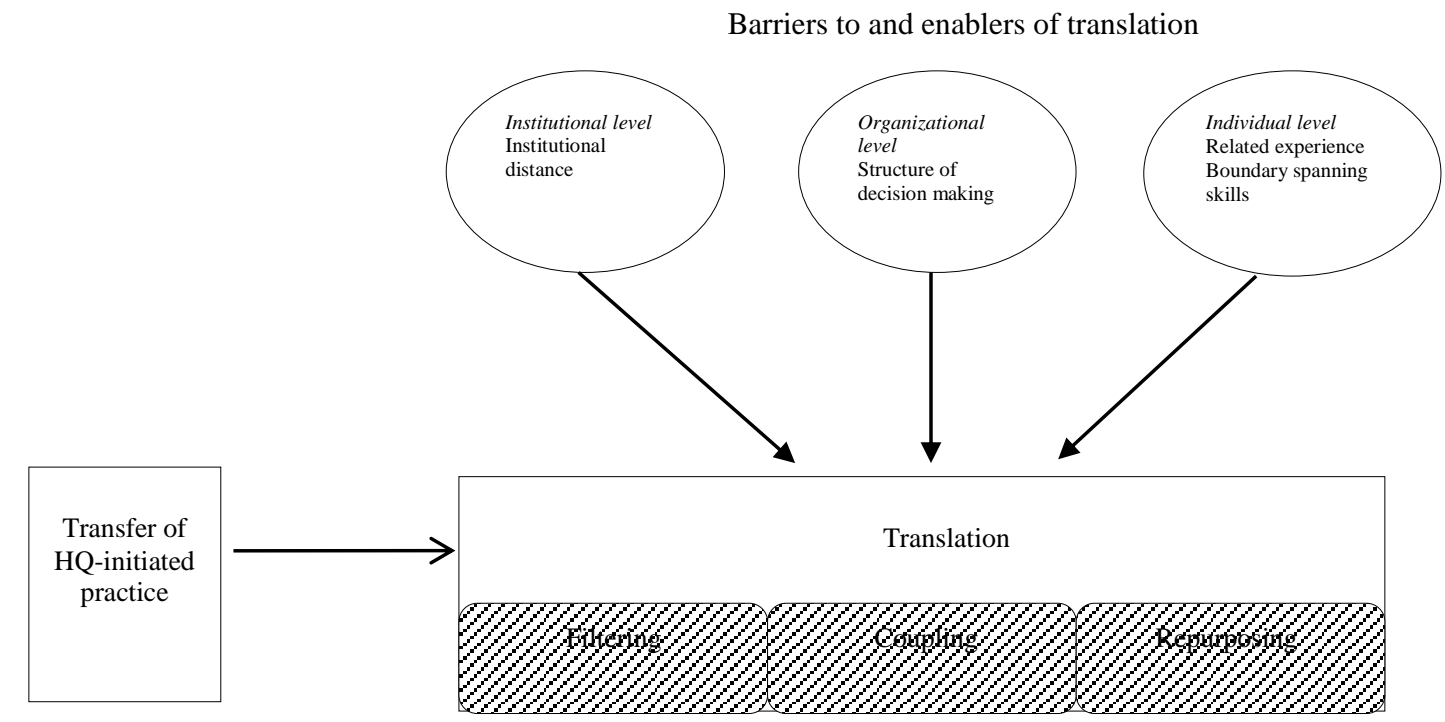

Individual-level processes undertaken by translators 
Figure 2 An extended framework of the micro-processes of translation of a transferred practice from HQ to subsidiaries

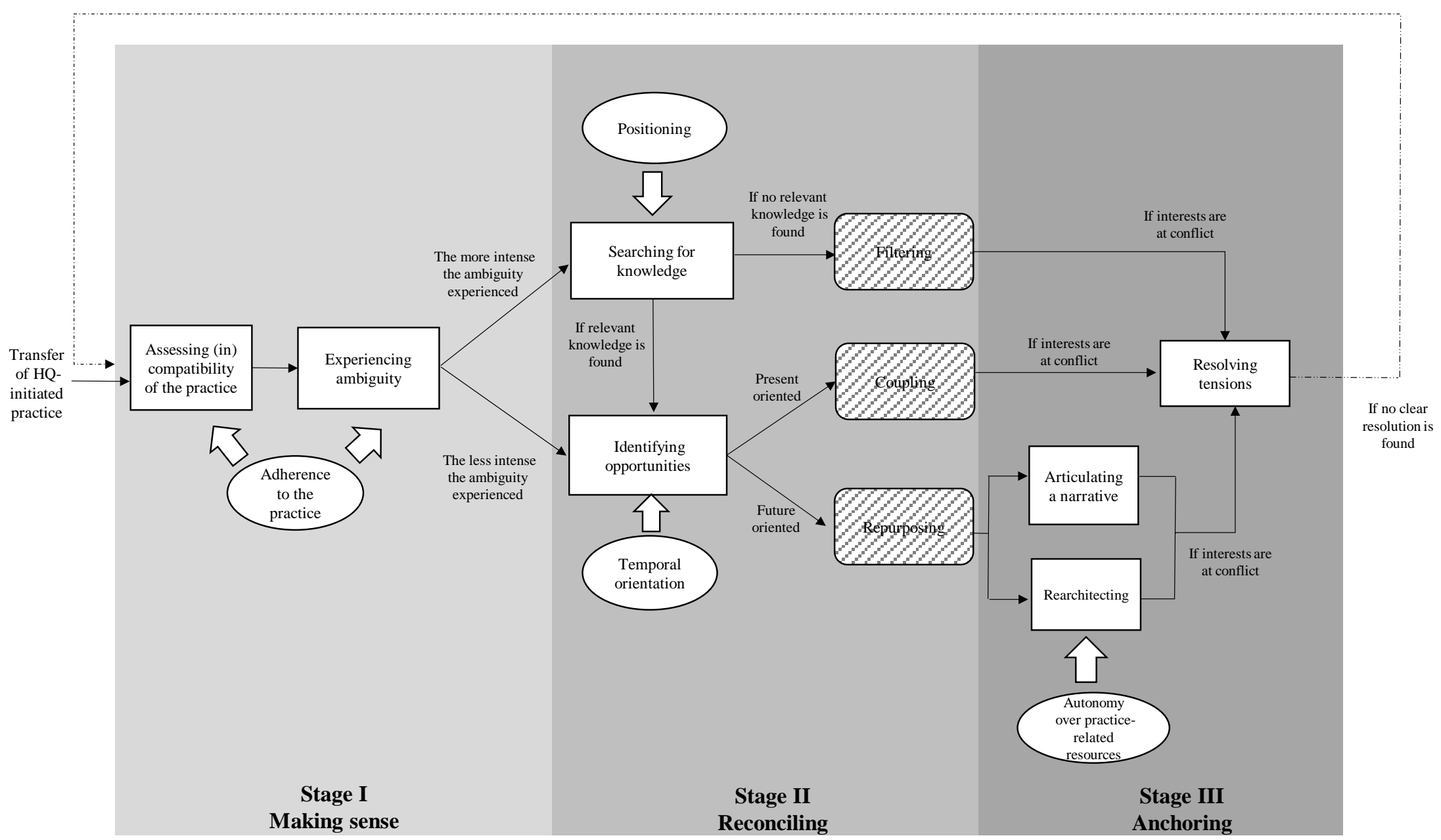

${ }^{\mathrm{a}}$ Micro-processes appear in rectangular boxes. Contextual conditions appear in ovals and are observed at the individual level (i.e. associated to the translators). Types of translation appear in shaded boxes. Solid arrows represent the triggering of the next micro-process. Block white arrows represent the influence of contextual conditions on specific micro-processes. The three stages are differentiated in three shades of grey. 
Table $1 \mathrm{MNE}$ and subsidiaries general information

\begin{tabular}{|l|l|c|c|c|c|}
\hline Country of origin & \multicolumn{4}{l|}{ United Kingdom } \\
\hline Total number of employees worldwide & 17,000 \\
\hline $\begin{array}{l}\text { Number of countries with overseas } \\
\text { subsidiaries }\end{array}$ & \multicolumn{3}{|l|}{} \\
\hline & $\begin{array}{c}\text { French } \\
\text { subsidiary }\end{array}$ & $\begin{array}{c}\text { Danish } \\
\text { subsidiary }\end{array}$ & $\begin{array}{c}\text { Dutch } \\
\text { subsidiary }\end{array}$ & $\begin{array}{c}\text { Brazilian } \\
\text { subsidiary }\end{array}$ & $\begin{array}{c}\text { American } \\
\text { subsidiary }\end{array}$ \\
\hline $\begin{array}{l}\text { Size of the subsidiary } \\
\text { employees) }\end{array}$ & 2,250 & 120 & 75 & 2,600 & 6,000 \\
\hline Year of acquisition & 1990 & 1980 & 1986 & 2007 & 1996 \\
\hline Year of foundation & 1980 & 1870 & 1960 & 1968 & 1953 \\
\hline
\end{tabular}

${ }^{\text {a}}$ Subsidiary size at the time of the transfer of CSRR

Table 2 Overview of data sources

\begin{tabular}{|c|c|c|c|}
\hline Type of data & Description & Quantity & Use in the analysis \\
\hline Interviews & $\begin{array}{l}\text { First round: } 27 \text { semi- } \\
\text { structured interviews; } \\
\text { between } 45 \text { and } 60 \text { minutes } \\
\text { each }\end{array}$ & $\begin{array}{l}27 \text { interviews (6 at } \\
\mathrm{HQ}, 5 \text { in French, } 4 \\
\text { in Danish, } 3 \text { in } \\
\text { Dutch, } 5 \text { in } \\
\text { Brazilian, and } 4 \text { in } \\
\text { American } \\
\text { subsidiaries) }\end{array}$ & $\begin{array}{l}\text {-Tracking the translation processes } \\
\text { of CSRR in subsidiaries } \\
\text {-Understanding } \\
\text { the context of CSRR transfer. } \\
\text { - Learning the original characteristics } \\
\text { of the prototype }\end{array}$ \\
\hline $\begin{array}{l}\text { Follow-up } \\
\text { interviews }\end{array}$ & $\begin{array}{l}\text { Second round: } 20 \text { e-mail } \\
\text { interviews }\end{array}$ & $\begin{array}{l}20 \text { interviews ( } 2 \text { at } \\
\mathrm{HQ}, 4 \text { in French, } 2 \\
\text { in Danish, } 3 \text { in } \\
\text { Dutch, } 5 \text { in } \\
\text { Brazilian, and } 4 \text { in } \\
\text { American } \\
\text { subsidiaries) }\end{array}$ & $\begin{array}{l}\text {-Confirming initial findings } \\
\text {-Clarifying issues } \\
\text {-Expanding interesting topics }\end{array}$ \\
\hline $\begin{array}{l}\text { Internal } \\
\text { documents }\end{array}$ & $\begin{array}{l}\text { Global code of conduct, } \\
\text { CSRR principles, and } \\
\text { methodologies and } \\
\text { references. Manual for } \\
\text { social and environmental } \\
\text { indicators. E-mail } \\
\text { conversations between HQ } \\
\text { and subsidiaries. Video- } \\
\text { conference transcripts. }\end{array}$ & 100 pages & $\begin{array}{l}\bullet \text { Reconstructing the CSRR } \\
\text { translation } \\
\text {-Identification of the three types and } \\
\text { micro-processes of translation }\end{array}$ \\
\hline $\begin{array}{l}\text { Information on } \\
\text { the subsidiaries' } \\
\text { websites }\end{array}$ & $\begin{array}{l}\text { General information about } \\
\text { the subsidiaries' history, } \\
\text { CSR and CSRR. }\end{array}$ & 400 pages & $\begin{array}{l}\text {-Tracking CSRR translation } \\
\text { - Reconstructing subsidiaries' } \\
\text { histories and context } \\
\text {-Triangulating informants' claims }\end{array}$ \\
\hline $\begin{array}{l}\text { Annual and } \\
\text { CSR reports }\end{array}$ & 2007 to 2015 & $\begin{array}{l}20 \text { reports }(1,500 \\
\text { pages })\end{array}$ & $\begin{array}{l}- \text { Reconstructing CSRR evolution at } \\
\text { the MNE } \\
\text { - Fine-grained tracking of historical } \\
\text { events and changes in the structure of } \\
\text { CSR } \\
\text {-Triangulating of informants' claims }\end{array}$ \\
\hline Business press & $\begin{array}{l}\text { Articles about the MNE } \\
\text { and its subsidiaries, } 2007 \\
\text { to } 2015 \text {. }\end{array}$ & 500 pages & $\begin{array}{l}\text {-Identifying institutional pressures } \\
\text { and translation of CSRR at the } \\
\text { subsidiary level } \\
\text {-Triangulating informants' claims }\end{array}$ \\
\hline $\begin{array}{l}\text { Government } \\
\text { information }\end{array}$ & $\begin{array}{l}\text { CSRR official reports and } \\
\text { documents }\end{array}$ & 200 pages & $\begin{array}{l}\text {-Identifying national CSRR laws } \\
\text {-Understanding national trends of } \\
\text { CSRR }\end{array}$ \\
\hline
\end{tabular}


Table 3 Prototype of CSRR as originally devised by the HQ

\begin{tabular}{|l|l|}
\hline $\begin{array}{l}\text { Motivations (Kolk, 2010; Maignan \& } \\
\text { Ralston, 2002) }\end{array}$ & $\begin{array}{l}\text { Mostly instrumental (Aguilera et al., 2007): Attract capital from } \\
\text { responsible investment community and new talent; minimize risk; } \\
\text { enhance MNE reputation and competitiveness; assess global CSR } \\
\text { performance according to key six areas; ensure data reliability and } \\
\text { completeness }\end{array}$ \\
\hline $\begin{array}{l}\text { Reporting standards and guidelines } \\
\text { (Fortanier et al., 2011; Kolk, 2004) }\end{array}$ & $\begin{array}{l}\text { ISO 14001, Carbon Disclosure Project and reporting criteria } \\
\text { established by FTSE4GOOD and DJSI }\end{array}$ \\
\hline Reporting scope (Kolk, 2004) & $\begin{array}{l}\text { Global }{ }^{\mathrm{b}} \text { on six areas: employee diversity, health and safety, employee } \\
\text { engagement, community investment, waste and } \mathrm{CO}_{2} \text { emissions } \\
\text { Selected case studies from subsidiaries }\end{array}$ \\
\hline $\begin{array}{l}\text { Systems for organizing reporting } \\
\text { (Kolk, 2004) }\end{array}$ & $\begin{array}{l}\text { Documents: Global code of conduct and principles and methodologies } \\
\text { for reporting, CSRR references, manual for social and environmental } \\
\text { indicators, list of items and relevant indicators } \\
\text { ICT systems: Global intranet platform, data gathering and performance } \\
\text { management system }\end{array}$ \\
\hline $\begin{array}{l}\text { Stakeholder dialogue and feedback } \\
\text { (Kolk, 2004; Young \& Marais, 2012) }\end{array}$ & $\begin{array}{l}\text { Forums and panels with external stakeholders centrally organised by } \\
\text { the HQ. Internal staff surveys and intranet feedback processes }\end{array}$ \\
\hline
\end{tabular}

(Kolk, 2004; Young \& Marais, 2012) the HQ. Internal staff surveys and intranet feedback processes

${ }^{a}$ The HQ discouraged adoption of the Global Reporting Initiative and signatories to the UN Global Compact.

$\mathrm{b}$ The HQ discouraged the development of local CSR reports along with the publication of website information about CSR activities.

Table 4 Data structure: Micro-processes of translation

\begin{tabular}{|l|l|l|}
\hline $\begin{array}{l}\text { Examples of activities manifested in the data (First- } \\
\text { order concepts) }\end{array}$ & $\begin{array}{l}\text { Micro-processes of translation } \\
\text { (second-order constructs) }\end{array}$ & $\begin{array}{l}\text { (Aggregate } \\
\text { dimensions) }\end{array}$ \\
\hline $\begin{array}{l}\text { Drawing comparisons between transferred and existing } \\
\text { practices } \\
\text { Negatively defining transferred practice } \\
\text { Reflecting on the value of the transferred practice }\end{array}$ & $\begin{array}{l}\text { Assessing (in) compatibility of the } \\
\text { practice }\end{array}$ & Making sense \\
\hline $\begin{array}{l}\text { Having doubts about the practice } \\
\text { Lacking common ground }\end{array}$ & Experiencing ambiguity & Reconciling \\
\hline $\begin{array}{l}\text { Monitoring competitors' behavior } \\
\text { Reaching peers and local stakeholders } \\
\text { Raising queries in communication channels }\end{array}$ & Searching for knowledge & \\
\hline $\begin{array}{l}\text { Envisioning the trajectory of CSRR in relation to } \\
\text { anticipated events }\end{array}$ & Identifying opportunities & \\
$\begin{array}{l}\text { Examining future outcomes of the translation of CSRR } \\
\text { Making practical and normative judgements in } \\
\text { response to dilemmas }\end{array}$ & & \\
\hline $\begin{array}{l}\text { Devising problem-solving approaches } \\
\text { Using moral accounts }\end{array}$ & Articulating a narrative & \\
\hline $\begin{array}{l}\text { Changing existing processes } \\
\text { Introducing new artifacts } \\
\text { Reconfiguring relationships }\end{array}$ & Re-architecting & \\
\hline $\begin{array}{l}\text { Addressing concerns } \\
\text { Negotiating terms with HQ }\end{array}$ & Resolving tensions \\
\hline
\end{tabular}




\section{NOTES}

${ }^{1}$ The "plus" is inclusive of other groups (e.g., asexual, intersex, queer, questioning).

${ }^{2}$ Our gatekeepers were the former Global Head of Corporate Responsibility and the Corporate Responsibility Reporting Manager. Two authors had an initial meeting with the first gatekeeper to discuss the research project, and the first author subsequently met separately with the two gatekeepers and negotiated access to subsidiaries.

${ }^{3}$ Size may indicate differences in the subsidiaries' access to knowledge and resources in other parts of the MNE (Birkinshaw \& Hood, 1998). Larger subsidiaries may acquire less knowledge from other MNC units than smaller subsidiaries because they are able to generate more knowledge themselves (Minbaeva, Pedersen, Björkman, Fey, \& Park, 2003). Older subsidiaries have had more time to become embedded in the host location (Rabbiosi \& Santangelo, 2013) and thus accumulate and develop deeper knowledge stock and capabilities (Noorderhaven \& Harzing, 2009), which in turn can make them more innovative (Foss \& Pedersen, 2002; Minbaeva et al., 2003). Subsidiary autonomy is negatively related to knowledge flows to and from HQ (Noorderhaven \& Harzing, 2009).

${ }^{4}$ National documents and reports were studied in preparation for the interviews to understand CSRR in France, Denmark, the Netherlands, Brazil, and the United States. This allowed assessment of the interviewees' awareness of existing national regulation, guidelines, or networks.

${ }^{5}$ Stages 4 and 5 were contemporaneous.

${ }^{6}$ These iterations relate to the extended framework and were subsequent to the coding conducted in Stages 3 to 5. Despite being presented sequentially, in reality, the cycles of coding specific constructs (i.e., micro-processes, translation types, contextual conditions) were not entirely independent of the iterations in our extended framework. Any re-arrangement of the coding in Stages 3 to 5 was reflected in the extended framework.

${ }^{7}$ North America; Latin America; the United Kingdom and Ireland; Europe, Middle East, and Africa; and Asia Pacific.

${ }^{8}$ UN Special Representative John Ruggie proposed a framework on business \& human rights to the UN Human Rights Council in June 2008 resting on three pillars: protect, respect and remedy. 